\title{
Impact of micro hydro power plants on transient stability for the micro grid $20 \mathrm{kV}$ system
}

\author{
Syarifuddin Nojeng ${ }^{1}$, Syamsir $^{2}$, Reny Murniati ${ }^{3}$ \\ 1,2Department of Electrical Engineering, Universitas Muslim Indonesia, Makassar, Indonesia \\ ${ }^{3}$ Department of Electrical Engineering, Universitas Sawerigading, Makassar, Indonesia
}

\begin{tabular}{l} 
Article Info \\
\hline Article history: \\
Received Oct 1, 2020 \\
Revised Oct 29, 2021 \\
Accepted Nov 6, 2021 \\
\hline
\end{tabular}

Keywords:

Distributed generation

Micro grid

Mini hydro power plant

Transient stability

\begin{abstract}
Transient stability analysis is conducted to determine the ability of the electric power system in maintaining the operating stability after a major disturbance. The disturbance can be trigger an impact on the stability of the rotor angle, voltage, and system frequency which can cause loss of synchronization. In this paper, the impact of the interconnection of the Tombolo-Pao mini hydro power plant (MHPP) on the stability of the system was analyzed by several scenarios to determine the behavior of system parameters in a $20 \mathrm{kV}$ system interconnection network. This research is an implementation of regulatory provisions relating to the study of the connection to the PLN distribution network through by regulator. Based on the result of simulation study, transient stability of generators at TomboloPao power plant about 0.1 second, will not occur with network configuration according to modeling activation of anti-islanding protection of Tombolo Pao Power Plant which is set by 2 second. The simulation results show that the location of the disturbance in the electric power system has been influenced by the behavior of the power plant (synchronous generator) which can lead to the instability of the micro-hydro connected to the micro-grid system $20 \mathrm{kV}$.
\end{abstract}

This is an open access article under the CC BY-SA license.

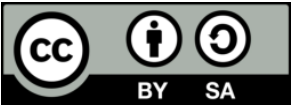

\section{Corresponding Author:}

Syarifuddin Nojeng

Department of Electrical Engineering

Universitas Muslim Indonesia

Urip Sumoharjo St. km.05, Makassar, Indonesia

Email: syarifuddin.nojeng@umi.ac.id

\section{INTRODUCTION}

Transient stability analysis is carried out to determine the ability of the electric power system to maintain operating stability after a major disturbance. The disturbance can have an impact on the stability of the rotor angle, voltage, and system frequency which can cause loss of synchronization. The stability condition is the validity of the conditions for connecting the generator to PLN's distribution network, which is the Regulation of the Minister of Energy and Mineral Resources NO. 12/ESDM/2014 concerning purchase of electricity energy from hydropower plants to the State of Electricity Company (PT. PLN) and provisions of the board of directors of PT. PLN through the Regulation No.0357.K /DIR/2014, concerning guidelines for connecting renewable energy power plants to distribution systems PLN [1]. It is a challenge for electricity providers to always provide a reliable and sustainable electricity supply by building renewable plants that can improve the appearance of the system [2]. Transient stability analysis is carried out to determine the ability of the electrical power system to maintain the initial stability of operation after a major disturbance that can have an impact on the stability of the rotor angle, voltage, and the system frequency which can cause the loss of synchronization, and in the worst conditions, it can cause the black-out system. The stability problems 
arising in micro-grid are very similar to those arising in large-sized power systems: transient stability, voltage stability, and small-signal stability. The micro-grid is represented as the combination of several distributed energy sources and the load on a small network system. With the limited power of distributed generators having a small-scale generator capacity in a micro-grid system, the effect is more reactive than the large generators. Therefore, is more important to know the dynamic behavior of synchronous machines or timedomain stability in power systems provides information about rotor angular stability and synchronization capability after major and minor disturbances, such as bus voltage drops or load changes [3]. An analysis of the voltage stability in the power system can be obtained by comparing the respective bus pre-fault voltages with the existing voltage calculated or observed after the fault is cleared [4]. In this paper, the main focus is the transient stability of the micro-grid, which is defined as the operating conditions in power systems. This paper is divided into five sections: introduction, literature review, problem statement, case study and result, and conclusion.

\section{LITERATURE STUDY}

The unbalance between load and generation in the power system will make the voltage and frequency system instability. Generally, on power system interconnection, there are two conditions of system stability: dynamic and transient stability. Dynamic stability is how the system looks when there is a dynamic change in the load. Meanwhile, transient stability in the system refers to the ability of a system to recover voltage and frequency by anticipating sudden load losses [5]. In case of sudden power failure, it needs to be maintained, so that the transient stability of the power system can reach an operating condition that can become a new equilibrium state or a stable state after the disturbance has disappeared [6]. Through the power flow analysis, it will provide information about the balance point of the power system used to determine the transfer capacity limit before the major disturbance occurs. The transient stability analysis with a simulation time domain is also required to observe transient system response during major disturbances [7]. When other major disturbances, such as a network line break where the plant is not connected to the power system grid, the short recovery time through the rapid protection system can improve system reliability and safety [8]. The ability of the system to maintain dynamic and transient stability is strongly influenced by several factors, especially those related to the transient parameters of the synchronous generator [9]-[11], in addition, the constant parameter of the control system device on the turbine. With regard to system stability, the impact on the micro-grid is not different from the stability of a large power system such as transient stability, voltage stability, and small frequency stability [12]. However, the limitation of small-scale generators (MHPP) with micro-grid systems, the response is more reactive than the large generators. The response to the disturbances in the micro-grid system can lead to transient instability, requiring a rapid disconnection of healthy parts. If the disturbance is allowed, the entire micro-grid system can experience voltage and frequency collapse [13]. In order to prevent the stress collapse of the micro-grid due to the overall disruption of the tissue, a technique for isolating the micro-grid is required which is called the islanding technique [14]-[16]. In general, transient stability studies and analysis are carried out to review the ability of the electric power system to maintain initial stability of operation after a major disturbance has an impact on the stability of the rotor angle, voltage, and system frequency which can cause out of step or out of sync, and in the worst conditions, it can cause black-out system [16], [17].

In a grid or transmission system, the thing that needs to be considered from the results of the transient stability analysis is the critical disconnection time (critical clearing time), which is the critical time limit before an out of step or out of sync is expected that circuit breaker (CB) will open the channel during disturbances. In addition, the transient stability study in the case of connecting renewable energy power plants to the PLN $20 \mathrm{kV}$ distribution system is also to see whether it will have an impact on the formation of an islanding operation or an isolated system so that the renewable energy power plant only supplies local loads, and is not connected to the PLN system [1]. This is because the renewable energy power plant connected to the $20 \mathrm{kV}$ system has a small role in destabilizing the grid system which is assumed to be a swing or slack or infinite bus whose capacity is very large and strong [17]. In a grid or transmission system, the thing that needs to be considered from the results of the transient stability analysis is the critical disconnection time (critical clearing time), which is the critical time limit before an out of step or out of sync is expected that circuit breaker (CB) will open the channel during disturbances. In addition, the transient stability study in the case of connecting renewable energy power plants to the PLN $20 \mathrm{kV}$ distribution system is also to see whether it will have an impact on the formation of an islanding operation or an isolated system so that the renewable energy power plant only supplies local loads and is not connected to the PLN system [1]. This is because the renewable energy power plant connected to the $20 \mathrm{kV}$ system has a small role in destabilizing the grid system which is assumed to be a swing or slack or infinite bus whose capacity is very large and strong [17]. In a grid or transmission system, the thing that needs to be considered from the results 
of the transient stability analysis is the critical disconnection time (critical clearing time), which is the critical time limit before circuit breaker (CB) will open the line during disturbances. In addition, the transient stability study in the case of connecting renewable energy power plants to the PLN distribution system $20 \mathrm{kV}$ is also to see whether it will have an impact on the formation of an islanding operation or an isolated system so that the renewable energy power plant only supplies local loads and is not connected to the PLN system [1]. This is because the renewable energy power plant connected to the $20 \mathrm{kV}$ system has a small role in destabilizing the grid system which is assumed to be a swing or slack or infinite bus whose capacity is very large and strong [17]. Some papers have been explored a new distributed secondary control scheme of distributed generators in islanded micro-grids [18]-[20]. While, time frequency regulation scheme strategy based active power control is presented in [21], [22], which can also to control of frequency system according to the reference value [23], [24]. Then, in [25], presented a transient current based micro-grid connected power system protection algorithm in micro-grid connected power systems for the fault location detection using wavelet method.

\section{PROPOSE METHOD}

Regulation of the Minister of Energy and Mineral Resources NO. 12/ESDM/2014 concerning purchase of electricity energy from hydropower plants to the PT. PLN (State of Electricity Company) and provisions of the Board of Directors of PT. PLN through the Regulation No.0357.K /DIR/2014, established a guideline for connecting renewable energy power plants to distribution systems PLN. The regulator (PLN) request purchase of electricity energy from hydropower plants to the PT PLN, should be an interconnection study before system will be operate. Therefore, with multiple generators that are in a balanced state, the following equation will apply,

$$
J_{i} \frac{d^{2} \theta_{m-i}}{d t^{2}}=T_{m=i}-T_{e-i}
$$

where,

$J=$ Momen Inertia

$\theta_{m i}=$ rotor angle of generator $-\mathrm{i}$

$T_{m-i}=$ Mechanical Torque of generator $-\mathrm{i}$

$T_{e-i}=$ Electric Torque of generator $-\mathrm{i}$

The (2) [1] can be expressed as (2),

$$
J \omega_{i} \frac{d^{2} \delta_{m-i}}{d t^{2}}=P_{m=i}-P_{e-i}
$$

where,

$\omega=$ angular rotation of generator-i

$\delta_{m i}=$ Displacement angle of mechanical generator $-\mathrm{i}$

$P_{m-i}=$ Mechanical power of generator $-\mathrm{i}$

$P_{e-i}=$ Electric power of generator $-\mathrm{i}$

Suppose there are 2 micro hydro generators connected to the interconnection network, then the power of each generator is as follows,

$$
\begin{aligned}
& P_{e 1}=\left|E_{1}^{\prime}\right|^{2}\left|Y_{11}\right| \cos \theta_{11}+\left|E_{1}^{\prime}\right|\left|E_{2}^{\prime}\right|\left|Y_{12}\right| \cos \left(\theta_{12}-\delta_{1}\right) \\
& P_{e 2}=\left|E_{2}^{\prime}\right|^{2}\left|Y_{22}\right| \cos \theta_{22}+\left|E_{2}^{\prime}\right|\left|E_{3}^{\prime}\right|\left|Y_{12}\right| \cos \left(\theta_{23}-\delta_{2}\right)
\end{aligned}
$$

Meanwhile, to determine the critical breaking angle, it can be solved by equations,

$$
\delta_{c r}=\frac{\omega_{s} P_{m}}{4 H} t_{c r}+\delta_{o}
$$

or, 


$$
t_{c r}=\sqrt{\frac{4 H\left(\delta_{c r}-\delta_{o}\right)}{\omega_{s} P_{m}}}
$$

where,

$\delta_{c r}=$ critical breaking angle

$H=$ inertia constant

$t_{c r}=$ critical Breaking Time

To analyze the stability of the transition, it can be done using the Lyavonov method, namely,

$$
\begin{gathered}
\dot{V}=\sum_{i=1}^{n} \frac{\partial V}{\partial x_{i}} \dot{X}_{i}=\sum_{i=1}^{n} \frac{\partial V}{\partial x_{i}} \dot{f}_{i}(x) \\
\dot{V}=\left[\frac{\partial V}{\partial X_{i}} \frac{\partial V}{\partial X_{i}} \ldots \frac{\partial V}{\partial X_{i}}\right]\left[\begin{array}{c}
f_{1}(x) \\
f_{2}(x) \\
\cdot \\
\cdot \\
f_{i}(x)
\end{array}\right]
\end{gathered}
$$

Simulation model,

$$
J \omega_{i} \frac{d^{2} \delta_{m-i}}{d t^{2}}=P_{m=i}-P_{e-i}
$$

when, generator-1 fault, where $P_{e-1}=0$, therefore,

$$
J \omega_{i} \frac{d^{2} \delta_{m-i}}{d t^{2}}=P_{m=i}-0
$$

In this research, several data from PT PLN (Persero) the Sulselrabar Region, especially from PT PLN (Persero), the Sulselrabar (P2B) as the Load Management Unit, requires for a certain period of time, short circuit level data, power transformer data, data for Incoming CB equipment. and $20 \mathrm{kV}$ feeders, cubicle data and protection relay data. Meanwhile, from the Tombolo Pao Power Plant, data is required, including the coordinates of the location of the power house and the dam, the distance to the existing PLN distribution network and generator data obtained from the manufacturer.

\section{CASE STUDY AND RESULT}

\subsection{Case study}

In case study, Tombolo Pao Hydro Power Plant $(1 x 2.5 \mathrm{MW})+(1 x 0.5 \mathrm{MW})$ connect to the PLN distribution system, it begins with the collection of field data which is generally obtained from the local PT PLN (Persero), namely PT PLN (Persero) Wilayah Sulselrabar, South Makassar area and Malino Rayon areas. The data required from the local PLN unit include:

- Single line distribution network diagram for the Tamaona feeder connected to the Tangka Link Substation, the Tamaona feeder connected to the Malino Substation (SS), peak load data and current peak load times and load forecast according to RUPTL 2015-2024.

- Data of distribution transformer capacity and loading and the distance between distribution transformers.

- Data on the length of the distribution network and the type of conductor used.

- Equipment data in distribution networks such as PMT, LBS/DCC, Recloser/Sectionalizer, Fuse and AVR.

- Data of types and brands of phase overcurrent protection relays and overcurrent to ground, TOC curve of relays, values of existing protection relay settings in the distribution network.

In the grid or transmission system, the thing that needs to be considered from the results of the transient stability analysis is the critical clearing time (CCT), which is the critical time limit before the outof-step or out of sync that is expected PMT will open the line disturbed before the CCT. However, in the study of transient stability in the case of connecting renewable energy power plants to the PLN $20 \mathrm{kV}$ distribution system, it is prioritized to see whether it will have an impact on the formation of an islanding operation or an isolated system so that the renewable energy power plant only supplies local loads and is not connected to the PLN system. This is because the renewable energy power plant connected to the $20 \mathrm{kV}$ system has a small role in disrupting stability in the grid system which is assumed to be a swing or slack or infinite bus whose capacity is much larger and stronger (robust). The transient stability study uses ETAP 12.6 software by selecting the operating pattern at maximum load (WBP) with the assumption that the largest 
noise current is obtained at maximum generation conditions. When the PLTMH operates in an islanding state, the CB at Tangka Substation (SS) which is supplied by the button feeder does not work. Likewise, with the Tamaona feeders will open CB on Tamaona substation as shown in Table 1. The short circuit current contribution of the feeder is very small due to its location which is quite far from SS Tombolo as shown in Table 2. This transient stability study, it is simulated by assuming a major disturbance, namely a 3-phase short circuit, which has an impact on the stability of the electric power system, especially to see its impact on power plant. The Governor and Exciter data for the generators of Tombolo Pao-HPP uses the existing generator data model in the ETAP 12.6 program. In this transient stability simulation, 2 scenarios were carried out by considering the location of the disturbance and its effect on the stability of TPMHPP.

Table 1. Short circuit current fault at bus\#7 (SS. Tamaona)

\begin{tabular}{|c|c|c|c|c|c|c|c|c|c|}
\hline \multicolumn{10}{|l|}{ Fault at bus: } \\
\hline Nominal kV & 20.000 & & & & & & & & \\
\hline \multicolumn{10}{|c|}{ Voltage c Factor 1.10 (User-Defined) } \\
\hline \multicolumn{2}{|c|}{ Contribution } & \multicolumn{2}{|c|}{ 3-Phase Fault } & \multicolumn{6}{|c|}{ Line-To-Ground Fault } \\
\hline From Bus & To Bus & $\% \mathrm{~V}$ & $\mathrm{kA}$ & $\% \mathrm{Vo}$ & tage at $\mathrm{Fr}$ & m Bus & & kA Symr & rms \\
\hline ID & ID & From Bus & Symm. rms & $\mathrm{Va}$ & $\mathrm{Vb}$ & $\mathrm{Vc}$ & Ia & $3 \mathrm{I} 0$ & $\mathrm{X} 0$ \\
\hline Bus7 & Total & 0.00 & 1.833 & 0.00 & 101.28 & 89.39 & 2.019 & 2.019 & $1.16 \mathrm{E}+002$ \\
\hline Bus6 & Bus7 & 0.04 & 0.019 & 0.03 & 101.28 & 89.40 & 0.015 & 0.002 & $1.10 \mathrm{E}+005$ \\
\hline Bus8 & Bus7 & 3.84 & 1.447 & 3.96 & 100.75 & 89.98 & 1.313 & 0.790 & $2.04 \mathrm{E}+002$ \\
\hline Bus12 & Bus7 & 1.60 & 0.464 & 3.86 & 101.47 & 87.54 & 0.787 & 1.350 & $1.89 \mathrm{E}+002$ \\
\hline
\end{tabular}

Table 2. Short circuit current fault at bus\#6 (SS Tombolo)

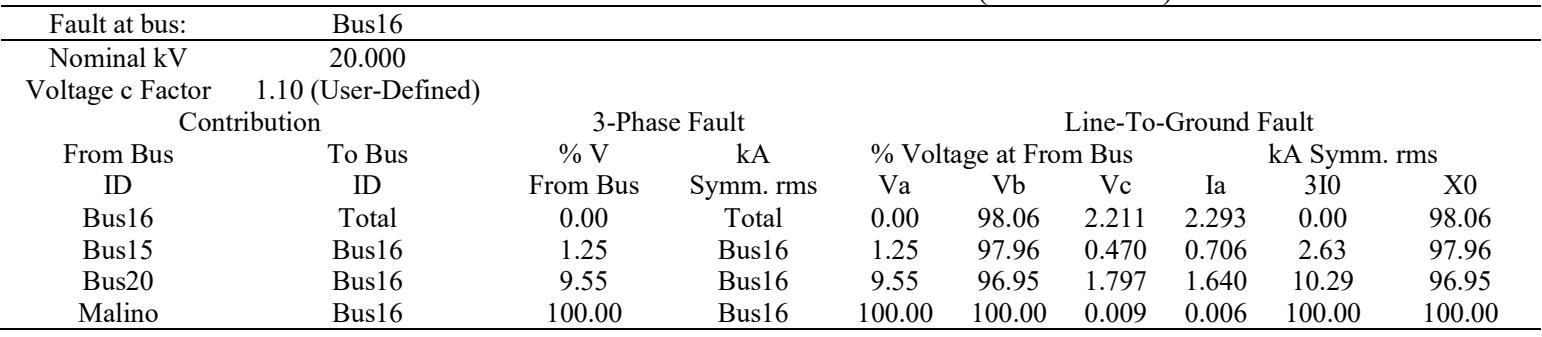

\subsection{Result}

This scenario is carried out to determine the transient stability of the PLTMH when there is a disturbance in the Tombolo-Pao feeder at a distance of about $2 \mathrm{~km}$ from the TPMHPP. The simulation results of transient stability analysis can be seen in Figure 1 to Figure 7 which describes the excitation conditions of the generator, active power, rotor angle, changes in speed, magnitude and angle of voltage and frequency (\%) on the Tangka Substation (SS.Tangka) and the $20 \mathrm{kV}$ bus at Tombolo-Pao Substation (SS.Tombolo) as closest bus with fault location.

Figure 2 shows the excitation current in generators at the Tombolo-Pao power plant before the fault and after the bus \# 7 fault. The change from initial conditions to steady state is around 0.1 second for both generators. Meanwhile, the amplitude of the excitation current increased to $1.7 \mathrm{pu}$ for generator\#1 and generator\#2 reached 1.4 pu.

Figure 3 shows the excitation voltage in generators at the Tombolo-Pao power plant before the fault and after the bus \# 7 fault. The change from initial conditions to steady state is around 0.1 second for both generators. Meanwhile, the amplitude of the excitation voltage increased to $1.2 \mathrm{pu}$ (generator\#1) and generator\#2 reached $1.5 \mathrm{pu}$.

Figure 4 shows the speed in generators at the Tombolo-Pao power plant before the fault and after the bus \# 7 fault. The change from initial conditions to steady state is around 0.1 second for both generators. Meanwhile, the amplitude of the speed generator\#1 increased to $1000 \mathrm{rpm}$ and generator\#2 reached $1300 \mathrm{rpm}$.

Figure 5 shows the output generators at the Tombolo-Pao power plant before the fault and after the bus \# 7 fault. The change from initial conditions to steady state is around 0.1 second for both generators. Meanwhile, the amplitude of the output generators\#1 increased to $1.2 \mathrm{MW}$ and generator\#2 reached 1.2 MW.

Figure 6 shows the power angle in generators at the Tombolo-Pao Power Plant before the fault and after the bus \# 7 fault. The change from initial conditions to steady state is around 0.1 second for both generators. Meanwhile, the amplitude of the power angle increased to 220-degree generator\#1, generator\#2 of 240 degree.

While in Figures 7 and 8, shown of the frequency and voltage system conditions of the nearest bus system when there is a disturbance on the bus closest to the Tombolo Pao Power Plant. With the operation of Tombolo Pao HPP $(2 \times 2.5 \mathrm{MW})+(1 \times 0.5 \mathrm{MW})$ connected to PLN distribution system, the important thing to 
note in preparing of emergency condition are: the formation of islanding operation is a condition where Tombolo Pao plant $(2 \times 2.5 \mathrm{MW})+(1 \times 0.5 \mathrm{MW})$ apart from PLN system but part of distribution network load still supplied from HPP Tombolo Pao. Based on the result of protection coordination study, the possibility of forming islanding operation at Tombolo Pao plant will not occur with network configuration according to modeling in Figure 1, and with activation of anti islanding protection SMHPP Tombolo Pao which is set of 2 second. The condition of islanding operation in accordance with the provisions of the Regulation of the Board of Directors No.357.K/DIR/2014 is not permitted under normal operating conditions, except in emergency conditions established under the authority of PLN. The underlying reason for not allowing islanding operations is to safeguard both human and equipment. Therefore, any renewable energy power plant must be equipped with anti-islanding protection.

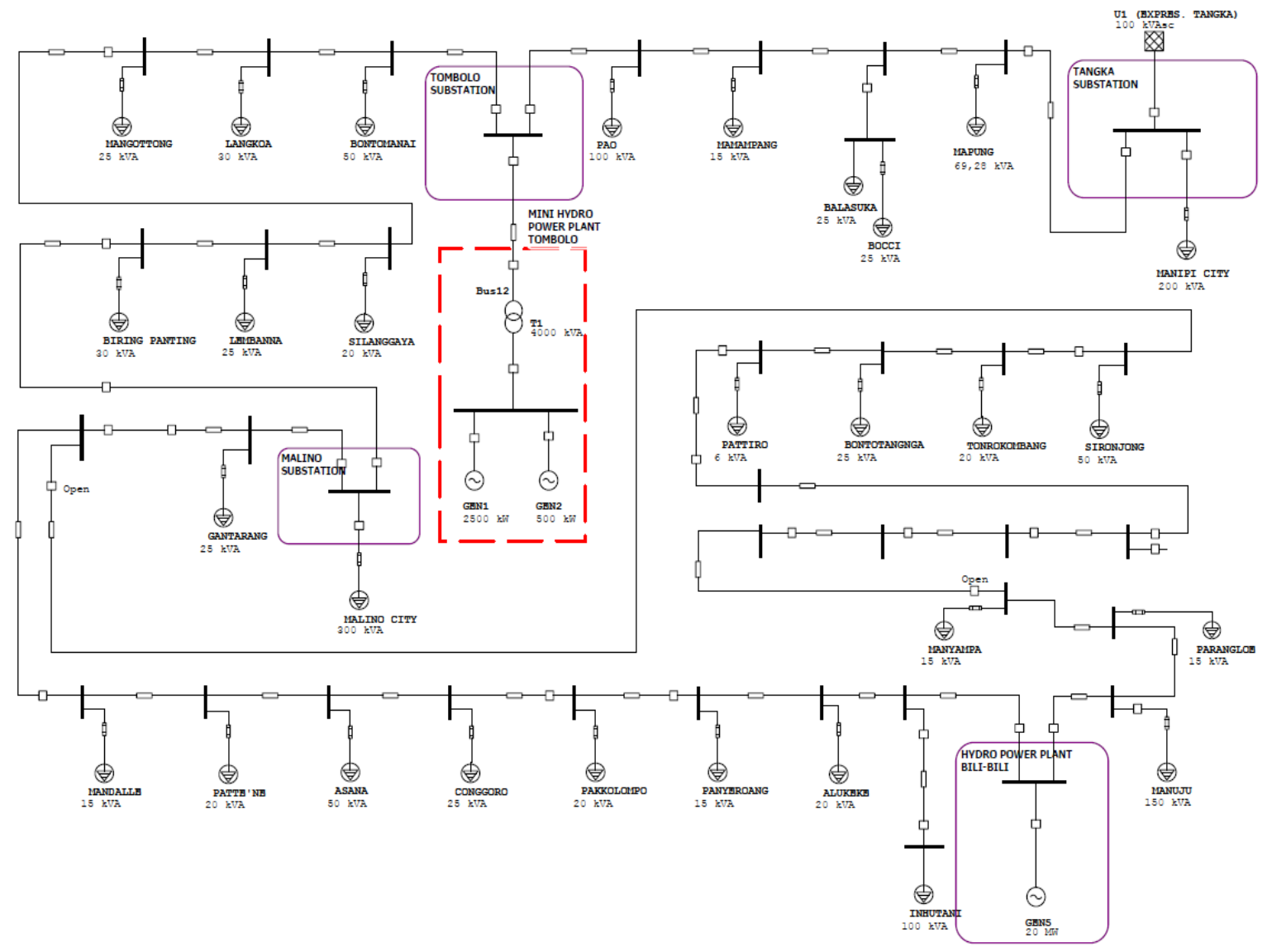

Figure 1. Single line diagram of Tombolo Pao plant interconnected with grid $20 \mathrm{kV}$ system

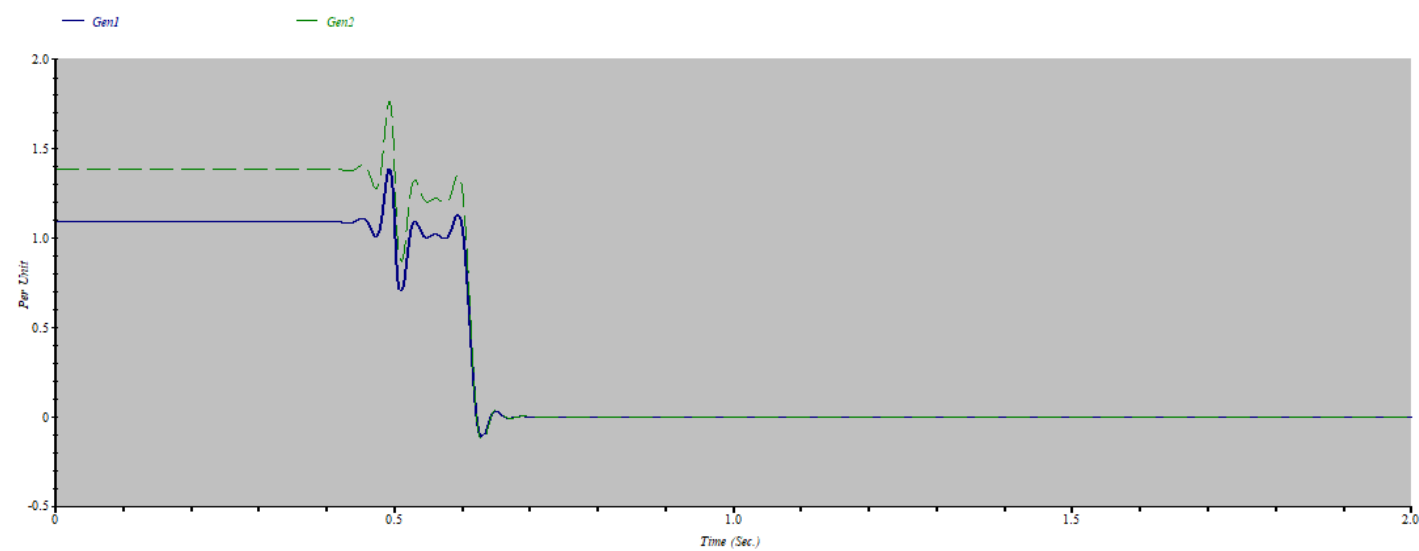

Figure 2. Excitation current on generators before and after fault 


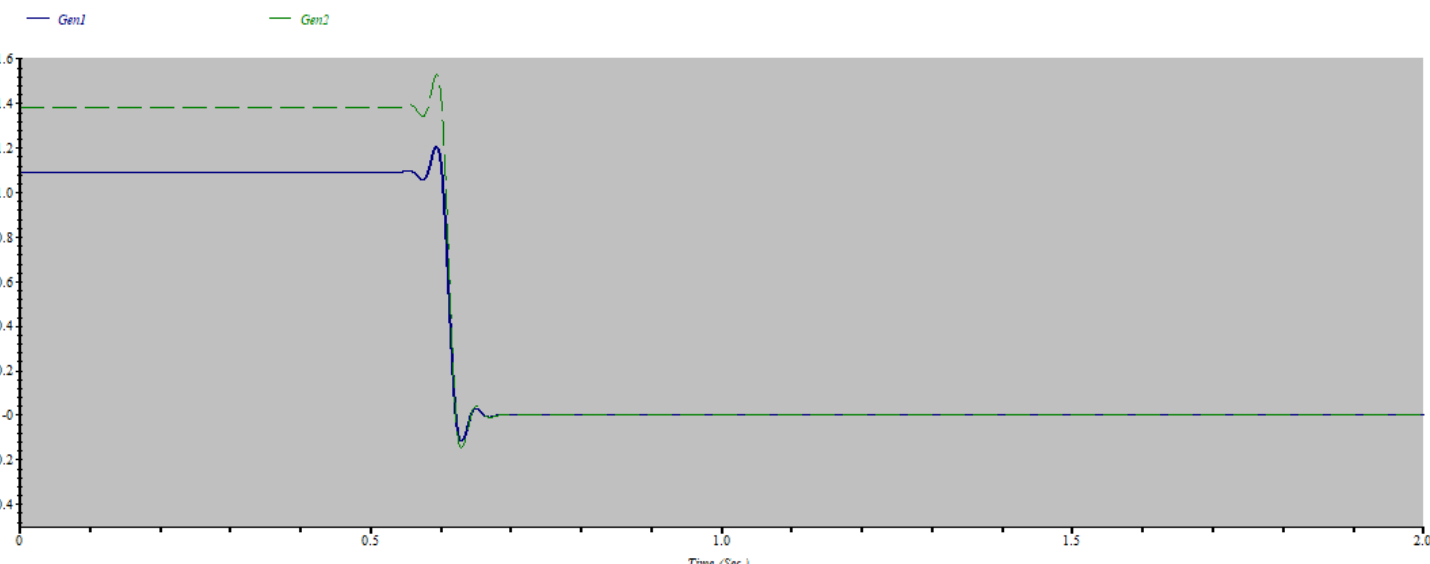

Figure 3. Excitation voltage on generators before and after fault

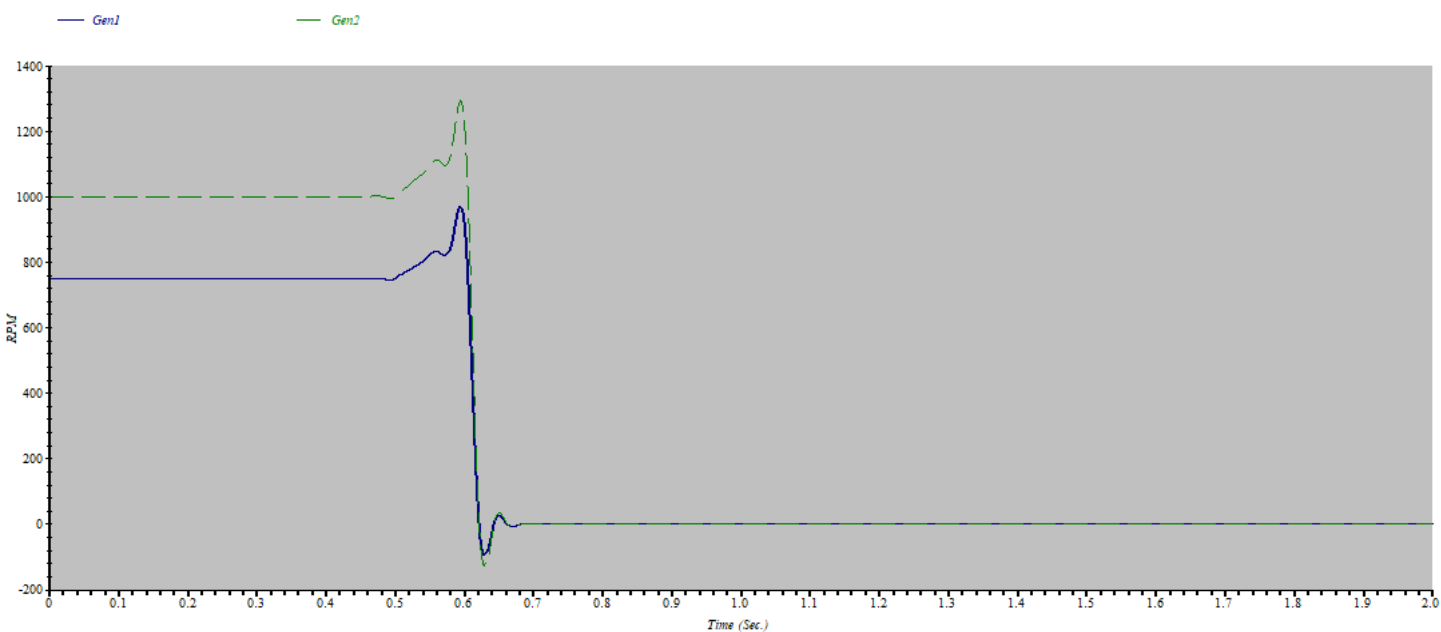

Figure 4. Generator speed on generators

- Genl $\quad-$ Gm?

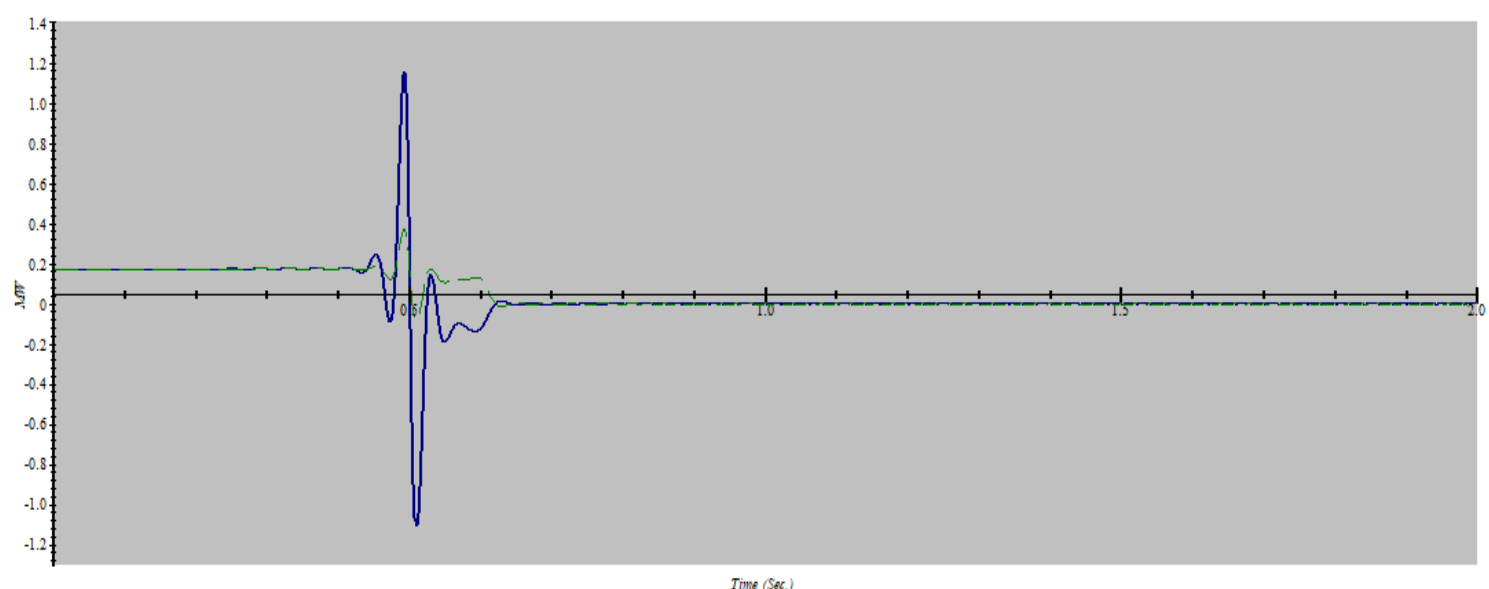

Figure 5. Output generator power before and after fault 

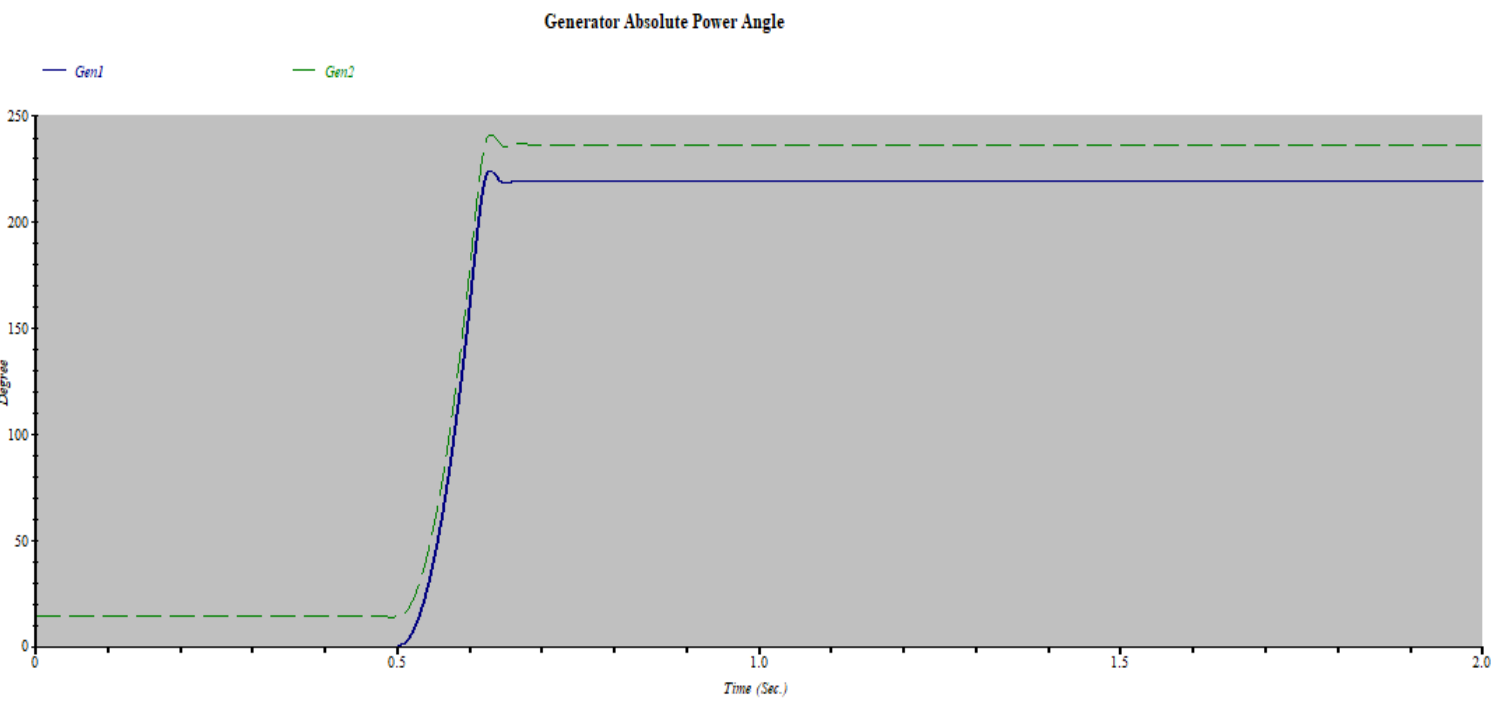

Figure 6. Power angle generator before and after fault

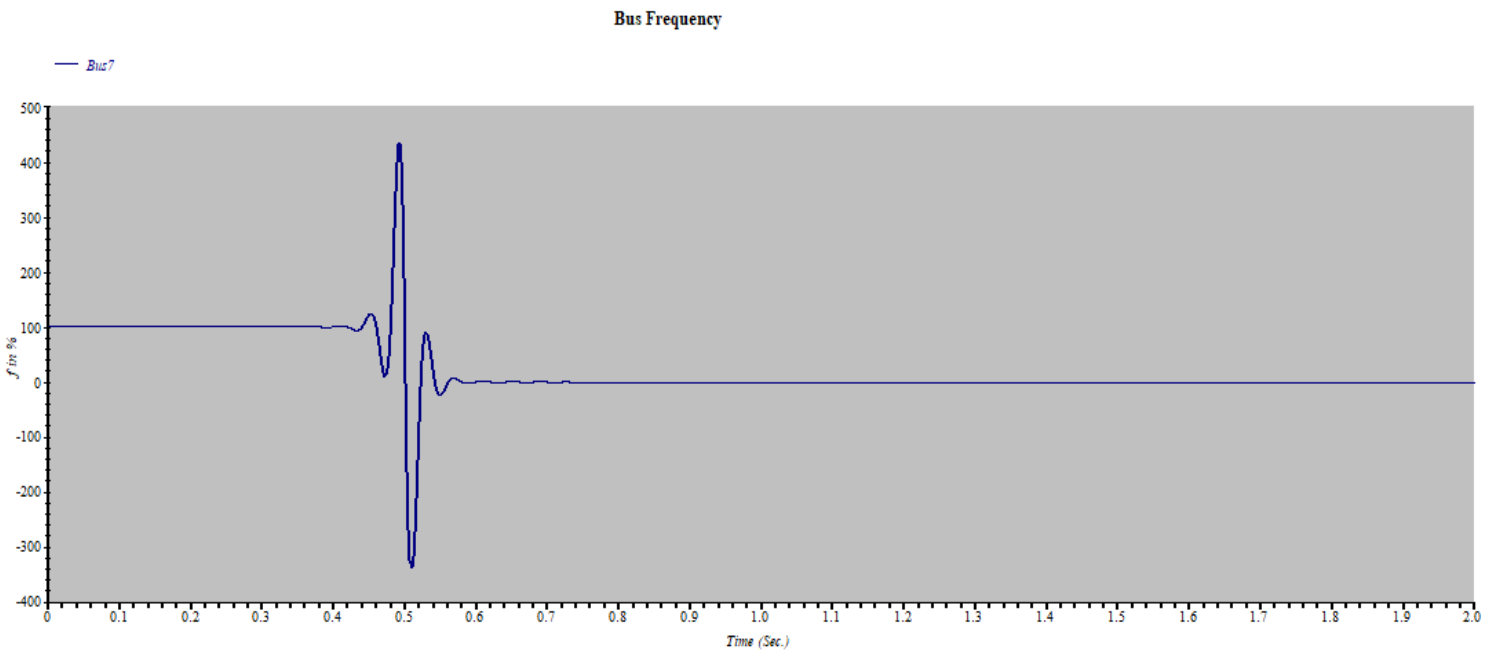

Figure 7. Frequency system on $20 \mathrm{kV}$ bus closet with fault location

Bus Voltage

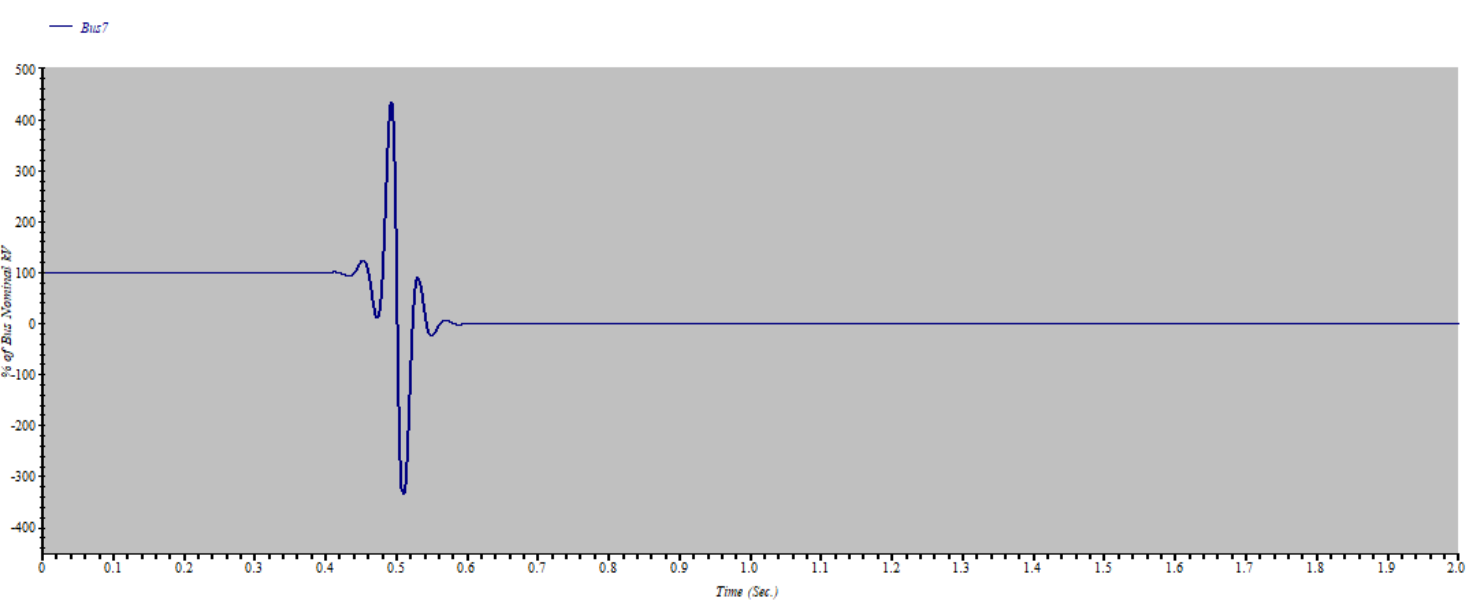

Figure 8. Voltage system (\%) on $20 \mathrm{kV}$ bus closet with fault location 


\section{CONCLUSION}

The simulation results show that the location of the fault in the electric power system has a big impact on the synchronous generator synchronous speed, power angle, voltage, and frequency. Based on the simulation results, it can be seen that the transient stability of the micro-grid can be increased by the response rate of the protection system (islanding system) and load shedding immediately after disturbance of the network. In this study, the results showed that the discharge of excess load can affect the frequency stabilization until a steady-state is reached. Therefore, in the future, studies are needed that can determine the optimal load shedding based on load shedding control as a very fast and optimal solution for increasing transient stability in the micro-grid. Base on the case study of HPP Tombolo Pao, the condition of islanding operation in accordance with the provisions of the Regulation of the Board of Directors No.357.K / DIR / 2014 is not permitted under normal operating conditions, except in emergency conditions established under the authority of PLN. Based on the result of simulation study, transient stability of generators at Tombolo Pao plant about 0.1 second, will not occur with network configuration according to modeling activation of anti-islanding protection of Tombolo Pao Power Plant which is set by 2 second.

\section{ACKNOWLEDGMENT}

The Authors would like to thank to Rector of Universitas Muslim Indonesia (UMI) and LP2S-UMI which has provided funding to conduct this research.

\section{REFERENCES}

[1] Center for Technology of Energy Resources and Chemical. Agency for the Assessment and Application of Technology, "Indonesia Energy Outlook 2017 - Clean Energy Technology Development Initiatives," ISBN 978602-74702-2-4. Jakarta. Indonesia. 2017.

[2] J. A. P. Lopes, N. D. Hatziargyriou, J. Mutale, P. Djapic, and N. Jenkins, "Integrating distributed generation into electrical power system: A review of driver challanges and opportunities," Electric Power system Res., pp. 1189-1203, 2007, doi: 10.1016/j.epsr.2006.08.016.

[3] J. Machowski, Z. Lubosny, J. W. Bialek, and J. R. Bumby, "Power System Dynamics: Stability and Control," 3rd Edition, Wiley, 2020.

[4] P. Kundur, J. Paserbe, V. Ajjarapu, and G. Andersson, "Definition and Classification of Power System Stability IEEE/CIGRE Joint Task Force on Stability Terms and Definitions," IEEE Transactions on Power Systems, vol. 19, no. 4, pp. 1387-1401, Sept. 2004, doi: 10.1109/TPWRS.2004.825981.

[5] K. R. Padiyar, "Power System Dynamics Stability and Control," 2nd ed, Indian Institute of Science, Bangolara, pp. 17-25, 2004.

[6] F. Milano, "Power System Modelling and Scripting," Springer-Verlag Berlin Heidelberg, Berlin, Heidelberg, pp. 70-79, 2010,

[7] S. Abhyankar and A. Flueck, "Simulating Voltage Collapse Dynamics for Power Systems with Constant Power Loads," IEEE Power and Energy Society General Meeting - Conversion and Delivery of Electrical Energy in the $21^{\text {st }}, 2008$, doi:10.1109/PES.2008.4596587.

[8] P. Demetriou, M. Asprou, J. Quiros-Tortos, and E. Kyriakides, "Dynamic IEEE Test Systems for Transient Analysis," IEEE Systems Journal, vol. 11, no. 4, pp. 2108-2117, Dec. 2017, doi: 10.1109/JSYST.2015.2444893.

[9] T. Weckesser, H. Jóhannsson, and J. Østergaard, "Impact of Model Detail of Synchronous Machines on Real-time Transient Stability Assessment," IREP Symposium, 2013, doi: 10.1109/IREP.2013.6629364.

[10] IEEE Power Engineering Society, "IEEE Recommended Practice for Excitation System Models for Power System Stability Studies,” IEEE Standart Board, 2016, doi: 10.1109/IEEESTD.2016.7553421.

[11] V. Kaur, C. Rza, and S. S. Mehta, "Impact Of Different Types Of Governors/Exciters On Transient Stability," IJREAT International Journal of Research in Engineering \& Advanced Technology, vol. 3, no. 2, April-May, 2015.

[12] W. We, J. Lei, X. Guo, and P. Yang, "Operation strategy of stand-alone microgrid," $20156^{\text {th }}$ International Conference on Power Electronics Systems and Applications (PESA), Hong Kong, 2015, pp. 1-8, doi: 10.1109/PESA.2015.7398886.

[13] A. H. K. Alaboudy, H. H. Zeineldin, and J. Kirtley, "Microgrid Stability Characterization Subsequent to FaultTriggered Islanding Incidents," IEEE Transactions on Power Delivery, vol. 27, no. 2, pp. 658-669, April, 2012, doi: 10.1109/TPWRD.2012.2183150.

[14] R. Majumder, "Some Aspects of Stability in Microgrids," IEEE Transactions on Power Systems, vol. 28, no. 3, pp. 3243-3252, Aug. 2013, doi: 10.1109/TPWRS.2012.2234146.

[15] S.-I. Jang and K.-H. Kim, "An islanding detection method for distributed generations using voltage unbalance and total harmonic distortion of current," in Power Delivery, IEEE Transactions on, vol. 19, no. 2, pp. 745-752, April, 2014.

[16] G. Wei, L. Wei, S. Chen, and W. Zhi, "Multi-stage underfrequency load shedding for islanded microgrid with equivalent inertia constant analysis," Int. J. Electr. power Energy Syst., vol. 46, pp. 36-39, 2013, doi: 10.1016/j.ijepes.2012.10.003. 
[17] IEEE Std. 1547, 2003. IEEE standard for interconnecting distributed resources with electric power systems, 2003. [Online]. Available: https://standards.ieee.org/standard/1547-2003.html

[18] O. Feddaoui, R. Toufouti, L. Djamel, and S. Meziane, "Active and reactive power sharing in micro grid using droop control," International Journal of Electrical and Computer Engineering (IJECE), vol. 10, no. 3, pp. 2235-2244, June 2020, doi: 10.11591/ijece.v10i3.pp2235-2244.

[19] A. Bidram, A. Davoudi, F. L. Lewis, and Z. Qu, "Secondary control of microgrids based on distributed cooperative control of multi-agent systems," IET Generation, Transmission \& Distribution, vol. 7, no. 8, pp. 822-831, 2013, doi: 10.1109/TPWRS.2013.2247071.

[20] Bidram, A. Davoudi, F. L. Lewis, and J. M. Guerrero, "Distributed cooperative secondary control of microgrids using feedback linearization," IEEE Transactions on Power Systems, vol. 27, no. 4, pp. 3462-3470, 2013, doi: 10.1109/TPWRS.2013.2247071.

[21] J. Veronica and N. Senthil Kumar, "Control strategies for frequency regulation in microgrids: A-review," Wind Engineering, pp. 1-16, 2019, doi: 10.1177/0309524X19868425.

[22] X. Lu, X. Yu, J. Lai, Y. Wang, and J. M. Guerrero, "A Novel Distributed Secondary Coordination Control Approach for Islanded Microgrids," IEEE Transactions on Smart Grid, vol. 9, no. 4, pp. 2726 -2740, July 2016, doi: 10.1109/TSG.2016.2618120.

[23] K. M. Priyadharshini, S. Srinivasan, and C. Srinivasan, "Detection of Power Quality Disturbances in Micro Grid Connected Power System,“ TELKOMNIKA (Telecommunication Computing Electronics and Control), vol. 14, no. 1, pp. 9-15, 2015, doi: 10.11591/telkomnika.v14i1.7232.

[24] Q. Sun, R. Han, H. W. Zhang, and Jianguo Zhou, "A multiagent-based consensus algorithm for distributed coordinated control of distributed generators in the energy internet," IEEE Transactions on Smart Grid, vol. 6, no. 6, pp. 3006-3019, 2015, doi: 10.1109/TSG.2015.2412779.

[25] S. Chandra Shekar, G. Ravi Kumar, and S. V. N. L. Lalitha, "A transient current based micro-grid connected power system protection scheme using wavelet approach," International Journal of Electrical and Computer Engineering (IJECE), vol. 9, no. 1, February 2019, pp. 14-22, 2019, doi: 10.11591/ijece.v9i1.pp14-22.

\section{BIOGRAPHIES OF AUTHORS}

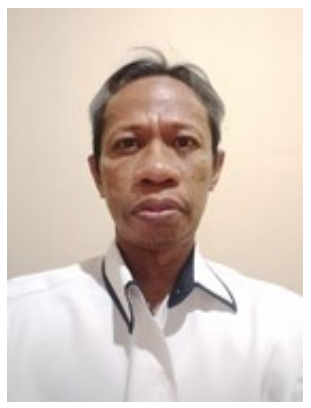

Syarifuddin Nojeng received the B.Eng. degree in electrical engineering from Hasanuddin University, Indonesia, in 1988, the M.E.E. degree from the Institute of Technology Bandung, (ITB) Indonesia, in 1994, and the Ph.D. Electrical Engineering from Universiti Teknologi Malaysia (UTM), Johor, Malaysia, in 2014. And also joint as researches at the Centre of Electrical Energy Systems (CESS-UTM) in 2011 to 2014. Recently, he is an Associate Professor and Vice Dean of Academic and Research in the Faculty of Engineering at Moslem University of Indonesia, Makassar. His research interest is in power operation and control systems, transmission pricing, power quality. He has been the winner of several grants for research from the Government of Indonesia and invited as presenter include keynote speaker several international conferences. Besides that, it still serves several international journals as reviewers. In recent years, he has focused on renewable energy technology and transmission usage allocation

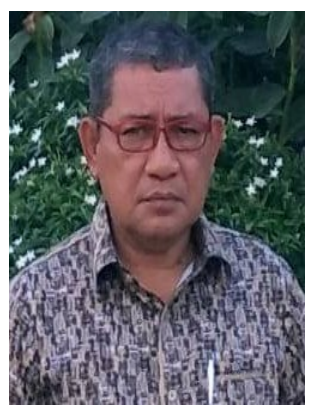

Syamsir received the B.Eng and M.E degree in electrical engineering from Universitas Muslim Indonesia, Makassar and Universitas Gajah Mada Yogyakarta, in 1992 and 2002 respectively. Currently, he is an Senior Lecturer in the Faculty of Engineering at Universitas Muslim Indonesia, Makassar. His research interest is in power plant operation and control.

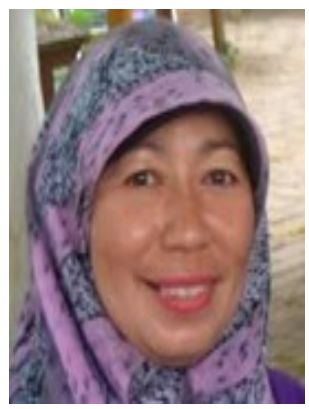

Reny Murniati is lecturer at Faculty of Electrical Engineering, Sawerigading. She obtained his B.Eng. in Electrical and Electronic Engineering from Sawerigading University, Indonesia. His completed of Master Degree in Power System from Hasanuddin University, Indonesia in 2008. He is the Head of Reseach Institute of Universitas Sawerigading. His research interest is in renewable energy, power transmission analysis. 